\title{
Ekonomik Krizlerin Nöroekonomi Kavramı Çerçevesinde Değerlendirilmesi
}

Serpil ALTINIRMAK* Ayşesu EYÜBOĞLU**

\section{$\ddot{O Z Z E T}$}

Finansal piyasalar incelendiğinde, belli aralıklarla farklı nedenlerden dolayı krizlerin yaşanmış olduğu görülür. Etkileri büyük çapta hissedilmiş olan bu krizlerin altında yatan en önemli nedenlerden birisi spekülatif balonlardır. Spekülatif balonların nasıl oluştukları hakkındaki araştırmalardan, bu zamana kadar anlamlı sonuçlar alınamamıştır. Balonların oluşumunu açıklamaya yönelik yeni bir disiplin olarak Nöroekonomi ön plana çıkmıştır. Nöroekonomi; nöroloji, psikoloji ve ekonomi bilim dalların bir araya getirerek, beyin dalgaları ile yatırım kararlarını ve yatırımc davranışlarını anlamayı amaçlamaktadır. Bu çalışmada, nöroekonomiden yararlanarak, finansal balonları açıklamaya yönelik çalışmalar incelenmiştir. Finansal balonlarla ortaya çıkan krizler incelenerek, nöroekonomi ve davranışsal finans açısından konu irdelenmiştir. Sonuç olarak, geleneksel finans teorileri ile açıklanamayan bu krizlerin, nöroekonomi ve davranışsal finans ile açıklanabileceği yapılan çalışmaların incelenmesiyle ortaya konmuştur.

Anahtar Kelimeler: Nöroekonomi, Finansal Balonlar, Küresel Krizler, Davranışsal Finans.

JEL Sinıflandirması: $G$ 01, G 02

\section{Evaluatin Of Economic Crises Within The Concept Of Neuroeconomics}

\section{ABSTRACT}

When the financial markets are analyzed it can be seen that crises ocur periodically due to different reasons. One of the main reasons is considered as speculative bubbles. Up to now, any significant result has not been obtained from related studies. At this point neuroeconomics is considered as a new discipline with the aim of examining the bubble formation. Neuroeconomics consisting of neurology, psychology and economics aims to analyze investment decisions and investors' behaviors via brain waves. In this study papers written for analyzing financial bubbles are taken into the consideration by using neuroeconomics. Furthermore crises caused from these bubbles were explored from the viewpoint of neuroeconomics and behavioral finance. According to the results of related studies these crises which can not be explained by traditional financial theories are examined in the light of neuroeconomics and behavioral finance.

Keywords: Neuroeconomics, Financial Bubbles, Global Crises, Behavioral Finance.

Jel Classification: $G$ 01, G 02

\footnotetext{
*Doç.Dr.Serpil Altınırmak, Anadolu Üniversitesi, EMYO, saltinirmak@anadolu.edu.tr

** Ayşesu Eyüboğlu, Anadolu Üniversitesi Sosyal Bilimler Enstitüsü, aysesu_9@hotmail.com
} 


\section{GİRiş}

20. yüzyılın başına kadar ekonomi ve finans teorileri, kişilerin yatırım kararlarını verirken rasyonel davrandıklarını, tüm bilgiler ışığında doğru karar verdiklerini savunmuştur. $\mathrm{Bu}$ durumda kişilerin, kendilerine maksimum getiri sağlayacağını düşündükleri menkul kıymetlere yatırım yaptıkları kabul edilmiştir. Ancak bu teorilerin tam anlamıyla gerçeği yansıtmadıkları psikoloji alanındaki gelişmelerin başlamasıyla görülmeye başlanmıştır. 20. yüzyıl sonlarına doğru, bilişsel psikolojinin gelişimi ile birlikte finansta yaşanan ancak rasyonel olarak açıklanamayan durumları anlamak için Davranışsal Finans ortaya çıkmıştır.

Davranışsal Finans; Psikoloji, sosyoloji, antropoloji bilimlerinden türetilmiş, insan davranışlarına dayanan kuramlardan yararlanarak finansal piyasaların davranışlarını anlamaya çalışır (Tufan, 2008: 22). Davranışsal Finans, kişilerin rasyonel olmadığını, yatırım kararı verirken maksimum getiriden ziyade duygularını kullanarak işlem yaptıklarını savunmaktadır. Yatırımcıların sahip olduğu dört davranış biçiminin, onların rasyonel karar verme sürecinin dışına çıkmalarına neden olduğundan bahseder. Bunlar; Aşırı iyimserlik, aşırı güven, korku kayıptan kaçma ve sürüye uyma davranışlarıdır. Aşırı iyimserlik, aşırı güven genellikle birlikte gözlemlenir ve kişilerin kendi yatırımlarına olması gerekenden fazla güvenmeleri ve bu sebeple riskleri düşük tahmin etmelerine neden olur. Sürüye uyma davranışı, kendi bilgi ve yeteneklerini kullanmak yerine diğer yatırımcıların yaptıklarını yapma durumudur. Bunun gibi davranışlar piyasalarda spekülatif balonların oluşmasına neden olmaktadır. Spekülatif balonlar, menkul değerlerin gerçek fiyatından sapma yaptığı ve yatırımcılarında, bu fiyatlardan işlem yaptığı duruma verilen isimdir. Balon patlamadığı sürece yatırımcılar spekülatif bir balonun içerisinde olduklarını fark etmezler. Balonun patlaması ise piyasalarda çeşitli alanlarda krizler meydana getirmektedir.

Dünya tarihinde ilk görülen spekülatif balon 1600'lı yıllarda yaşanan Lale Çılgınlığı balonudur. On altıncı yüzyılda Türkiye'ye gelen Viyanalı gezginler, gördükleri lale bahçelerinin güzelliğine hayran kalmışlar ve ülkelerine dönerken yanlarında lale soğanı götürmüşlerdir. Lale yetiştiriciliği bir çılgınlık haline gelerek Avrupa'yı etkisi altına almıştır. Lale soğanları o kadar popüler hale gelmiştir ki, henüz yetişmemiş olanlar için bile sözleşmeler imzalanmaya başlanmıştır. Balonunun en üst seviyelerinde, bazı lale soğanı çeşitlerine sahip olmak için Amsterdam kanalında bir ev satın alabilecek miktarda ödeme yapmak gerekli olmuştur. 1637 yılında, lale çılgınlığı balonu patlamış ve lale soğanları sadece birkaç kuruş değerine düşmüştür.

Lale çılgınlığını izleyen bir başka spekülatif balon, 1720’lerdeki Güney Denizi Balonu olmuştur. Bunu takiben 1929 yılı Büyük Buhranı, 2000 yılındaki Dot-Com Balonu ve son olarak 1930'lu yıllardaki Büyük Buhrandan sonraki en şiddetli kriz olan 2008 Küresel Finansal Krizini örnek gösterebiliriz. Sözkonusu krizleri, nöroekonomi kavramı çerçevesinde yapılan çalışmalar 1şığında incelemeye çalışacağız. 
Nöroekonomi, bilim dünyasına yeni bir bakış açısı getirerek yatırım kararı süreci ile beyin fonksiyonları arasındaki ilişkiyi incelemeye başlamıştır. İlk olarak Prof. Kevin McCabe tarafından, 1998 yılında George Mason University'de Nöroekonomi kavramı kullanılmıştır. 1999 yılında Paul Glimcher ve Michael Pratt, umulan ödüllere bağlantılı olarak "maymunların davranışı" üzerine yaptıkları nöroekonomik analizler içeren çalışmalarını yayınlamışlardır. Kaliforniya'daki Claremont Graduate University'deki Center for Neuroeconomics Studies direktörü Paul Zak'a göre, Nature Dergisi'nde yayınlanan bu çalışma, kıt kaynakların optimal tahsisi konulu bir anket olması sebebiyle nöroekonominin başlangıç noktasıdır (Soydal vd., 2010:218).

Nöroekonomi sinir bilimi, psikoloji ve ekonomi alanlarını bir araya getirerek deney ve gözlem yoluyla kişilerin karar verme süreçlerinin beyindeki bazı bölgelerde oluşan değişimlerden kaynaklandığını söylemektedir. İnsan beyni, anatomik olarak üç bölüm halinde tasarlanmıştır. Bu bölümlerin her birini katman olarak düşünmek mümkündür. Analitik karar alma gibi karmaşık süreçler dış katman alanına girer, motivasyonlar ve güdüler orta katmanda, psikolojik süreçler ise en iç katmanda gelişir. Bu kavramsal şema "Üçlü Beyin Modeli” olarak bilinir (Peterson, 2012:57).

Yatırım kararları için önemli olan bölümler, ön alın korteksi (prefrontal cortex) ve limbik sistemdir. Ön alın korteksi; Soyut düşünme, planlama, hesaplama, öğrenme ve stratejik karar alma ile ilgilidir. Limbik sistem ise beynin duygu motorudur. Korku, heyecan gibi ilkel motivasyon ve duyguların kaynağından oluşmaktadır. Limbik sistemin yatırımla ilgili iki önemli bölümü bulunmaktadır. Birincisi; Ödülün peşinden gitme, ikincisi; Kayıptan kaçınma devreleridir. Ödül arayışı, insanların çeşitli beklentilere hangi değeri verdiğini, amaçlarına ulaştıklarında kendilerini iyi hissetmelerini, motive olmalarını, yeniliklerin peşine düşmeyi kapsamaktadır. Araştırmalar, beynin zevk ve ödül ile ilgili olan kısmının alım satım sırasında aydınlandığını göstermektedir. Bu durum, yatırımcıların agresif bir biçimde alım satım yapmalarına ve sonuçta finansal balonların oluşumuna ve patlamasına neden olmaktadır (http://www.latimescom). Kayıptan kaçınma sistemi ise, korku ve tereddüdü harekete geçirir ve algıladığımız bir tehditten kaçınmamızı sağlar. Finans ile ilgili birçok önemli önyargı eğiliminin temelinde, ödül sistemi bulunmaktadır. Bu sistemin fazla çalışması, iyimserliğe, aşırı güvene ve bunun sonucunda aşırı risk alımına neden olmaktadır. Beynin kayıp sisteminin çalışması stres, sıkıntı, acı hatta panikle sonuçlanmaktadır. Kayıptan kaçınmaya yönelik davranışsal önyargı eğilimi hayal kırıklığı ve pişmanlığa neden olmaktadır.

\section{NÖROEKONOMİ İLE FINANSAL BALONLAR ARASINDAKİ İLIŞSİ}

Beyin, öğrenme ve diğer tüm zihinsel işlemlerin merkezidir. "Uyuyan dev" olarak da tanımlanan beyin, yaklaşık 100 milyar nörondan oluşur (Avcı ve Yağbasan 2008:3). Nöron, sinir sistemi içerisinde bulunur ve en önemli görevi diğer nöronlar ile bilgi transferini gerçekleştirmektir. İki nöron arasında bilgi transferini sağlayan beyin kimyasalı ise nöron taşıyıcılardır. Transfer, sinaps denen boşluktan, bir nörondan diğerine geçer ve bunları karşı 
taraftaki nöron taşıyıcıları alır (Peterson, 2012: 87). İki türlü nöron taşıyıcı vardır. Bunlar uyarıcı (excitatory) ve önleyici (inhibitory) nöronlardır. Beyin, nöron taşıyıcılar vasıtasıyla kalbe atmasını, ciğerlere nefes almasını, mideye sindirmesini emreder (http://neurogistics.com). Nöron taşıyıcı düzeylerinde herhangi bir değişim, duygusal değişimlere, huy değişikliklerine hatta depresyona neden olabilir. Beynin büyük bir bölümünde etkili olan nöron taşıyıcılar; Serotonin, dopamin, GABA (gamma-aminobutrik asit) ve asetilalkolindir.

Serotonin, önleyici bir nöron taşıyıcıdır. Başka bir deyişle beyni uyarmaz. Normal düzeyde seratonin stabil duygu durumu ve aşırı uyarıcı nöron taşıyıcıların dengelenmesi açısından çok önemlidir. Serotonin fazlalığı, anksiyeteye neden olurken azlığı, depresyona sebep olmaktadır (Peterson, 2012:89). Günümüzde depresyon tedavisi için kullanılan tüm ilaçlarda serotonin düzeyini arttırıcı maddeler bulunmaktadır. Dopamin; en önemli nöron taşıyıcı olarak düşünülebilir. Dopamin fazlalığı ya da azlığı odaklanma bozukluğu, unutkanlık, dikkat bozukluğu gibi problemlere neden olabilir. Dopamin ayrıca kişilerin bir işi yapma isteği ve hazzından da sorumludur. Bir amacın peşinden gidilmesini, isteğini ve motivasyonunu sağlamaktadır.

Nöron taşıyıcılarının yatırımcılar açısından önemi ise; Depresyon durumunda ödül sistemi, dopamin azlığından dolayı az çalı̧̧makta buna bağlı güven eksikliğine ve sonuç olarak riskten kaçınma eğilimine neden olmaktadır. Serotonin fazlalı̆̆ ise anksiyeteye neden olmakta ve sonuçta yatırımcılar, finansal kararlarında önyargılı olabilmektedirler.

2000 yılında psikiyatrist Randolph Nesse bir makalesinde, seratonin arttırıcı ilaç kullanan hastalarından bazılarının: "Eskisi kadar ince eleyip sık dokumuyorum ve gerçek tehlikelerden çok az kaygılanıyorum." dediğinden bahsetmektedir. Bu durum Nesse'in, yatırımcıların riski görmezden gelmesinin, antidepresan kullanımı ile ilgisinin olup olmadığını sorgulamasına neden olmuştur. Stanford Üniversitesi'nde profesör olan Brian Knutson'ın yapmış olduğu deneye göre; Antidepresan verilmiş deneklerin, tehdit algılarında azalma, sosyal davranışlarında artış gözlemlenmiştir. Sonuç olarak, bu özellikler "Aşırı boğa piyasası yatırımcılarının çoğalması ve aşırı iyimserliğin oluşmasını" sağlamaktadır (Peterson, 2012:101). Bir başka deyişle piyasa balonlarının oluşumuna ön ayak olmaktadır.

Kaliforniya Teknoloji Enstitüsü'nde (Caltech) nöroekonomi dalında çalışan ekonomi profesörü Alec Smith'e göre, sebebi ne olursa olsun birkaç insan bir araya gelip alım satım yapmaya başladıklarında, o piyasada balon oluşumu kaçınılmazdır (htpp://latimes.com).

Haziran 2014'te finansal balonların beyinde olan bir takım değişikliklerden kaynaklandığını açıklamak için deneysel piyasa balonu ortamları oluşturulmuş ve yatırımcıların davranışları gözlemlenmiştir.

Deneyde, 16 farklı deneysel balon ortamı oluşturulmuş ve fMRI (functional magnetic resonance imaging) ve kandaki oksijen seviyesini ölçmek için GLM (general linear method) kullanılarak farklı zamanlarda her deneyde ortalama 20 kişi olacak şekilde düzenleme 
yapılmıştır. Toplam 50 tur alım satım yapılması ve her deneğin elinde 100 birim risksiz varlık ve 6 birim riskli varlık bulunması sağlanmıştır. Deneklerin her turda sadece bir kere riskli varlığı kullanmalarına müsade edilmiştir. MRI sonuçlarına göre, beyindeki nükleus akkumbus bölümü hem alıma hem de satıma güçlü karşılık vermiştir. Nükleus akkumbus, motivasyonu ve bağımlılı̆̆ı kontrol eder ve istediğimiz bir şey olduğunda dopamin ile yüklenir. $\mathrm{Bu}$ bölümdeki aktiflik arttıkça, fiyatların yükseldiği görülmüştür. Beyin aktivitelerinin ölçümü aynı zamanda balonun ne zaman patlayacağını da göstermiştir. GLM grafiklerinde, kandaki oksijen seviyeleri doruk noktasına ulaştıktan sonra hızı bir düşüşe geçmiş aynı şekilde varlık fiyatları da düşüşe geçmiştir (Smith vd., 2014: 10503-10508).

Ancak her denekte aynı durum gözlenmemiştir. Bazıları fiyatların çok yüksek olduğunu anlayarak piyasadan çıkmış ve en yüksek getirileri elde etmiştir. Bu deneklerin MRI'larına bakıldığında, beyindeki interior insula denilen bölgenin aktif olduğu görülmüştür. Bu bölge, kişilerin fiziksel rahatsızlıklarında uyarı görevi gören bölgedir. Örnek olarak çok doyduğumuzda midemizin doluluk hissini, ya da kalbimizin çok hızlı attığındaki rahatsızlık hissini verebiliriz. Araştırmalar sonucunda, bu bölgenin riske karşı da uyarı görevi gördüğü anlaşılmıştır (htpp://www.latimes.com). Bu noktada 2008 krizinde en yüksek getiriyi elde etmiş olan Nassim Taleb'i örnek vermek mümkündür.

Alec Smith, deney sonunda varılacak en önemli sonucunun, Warren Buffett'in "Herkes açgözlü iken sen kork herkes korkarken sen açgözlü ol” sözü olduğunu vurgulamıştır.

\section{FINANSAL BALONLAR SONUCU OLUŞMUŞ ÖNEMLİ KRIZZLER}

Tarihte belli aralıklarla piyasalarda gündelik hayatı derinden etkileyen krizler meydana gelmiştir. Krizlerin çoğu farklı konularda ancak aynı nedenden meydana gelmiştir. Özellikle elde edilmesi kişilere haz veren varlıklardan dolayı ortaya çıkan finansal balon, belli süre sonra patlamış ve kriz ortamı oluşmuştur.

\subsection{Lale Çılgınlı̆̆ı}

Tarihte ilk kez bir finansal balonun patlaması sonucu ortaya çıkan kriz, Lale Çılgınlığ (Tulipmania)'dır. 1634 ile 1637 yılları arasında Hollanda'da gerçekleşmiş ve büyük bir finansal krize neden olmuştur. Anavatanı Türkiye olan Lale soğanı, ilk olarak Kanuni Sultan Süleyman zamanında Hollanda Büyükelçisi tarafından alınıp Hollanda’ya getirilmiştir. Bu dönemde Hollanda-İspanya bağımsızlık savaşının bitmesiyle olumlu bir hava içerisinde olan Hollanda'da piyasalar iyi durumda seyretmektedir. Rahatlık döneminde olunmasından dolayı piyasalarda spekülatif hareketler baş göstermeye başlamış ve zenginlik, lüks, refah ve statü gibi durumları sembolize eden lale soğanlarının fiyatları artışa geçmiştir. Fiyat artışları ve talebin giderek artmasıyla, lale soğanına özel bir piyasa bile oluşmuştur. İnsanlar bir tane lale soğanı için evlerini ipotek ettirme durumuna gelmiştir. 
Piyasada, "kırık" olarak ifade edilen ve kırçıllı bir görünüme sahip olan çiçekler en değerli laleleri oluşturmuştur. İfade edilen bu türün değeri, ancak arpacıktan çoğaltılabilmesi ve aynı motife sahip olma sürecinin çok uzun olmasından kaynaklanmıştır (Akıncı vd., 2014:722). Bu tür lalelerden üretilen arpacık sayısının çok sınırlı olması, daha çok değerlenmesine ve fiyatlarında hızla yükselmesine neden olmuştur. Fiyat artışlarına yol açan temel olgunun, standart piyasa yapısının işlemesi yerine, bireysel faydayı maksimize etmek için bir araç olarak kullanılan spekülasyon mekanizmasının olduğunu söylemek mümkündür (Flood ve Garber, 1980, s. 749). Piyasayı izleyen yatırımcılar, fiyatların artacağını düşünerek lale soğanına yatırım yapmaya başlamış hatta daha üretilmemiş olan lale soğanları için vadeli sözleşmeler imzalamışlardır.

Çok geçmeden durum tersine dönmeye başlamıştır. Lale soğanın üretiminin çok zor olması ve mevsim koşullarına bağlı olması, üretimde gecikmelere neden olmuştur. Vadeli sözleşmeler ile lale soğanına yatırım yapmış olan kişiler, yatırımlarının karşılığını alamamış ve sözleşme sahiplerine ödeme yapamaz hale gelmişlerdir. $\mathrm{Bu}$ durum, zincirleme bir reaksiyon oluşturmuş yatırımcılar, lale soğanı piyasasından hızla çekilmeye başlamışlardır. Sonuç olarak, balon patlamış ve fiyatlar hızlı bir düşüşe geçmiştir. Bir gayrimenkulün değerine eşit olan lale soğanı, bu değerin \%10 una bile satılamamıştır (Akıncı vd., 2014:724). Balonun patlaması ile hem lale yetiştiricileri hem de sözleşme sahipleri büyük zarar etmiştir.

\subsection{Güney Denizi Balonu}

Güney Denizi Şirketi (South Sea Company) 18.yy’da Güney Amerika'da faaliyet gösteren İngiltere kökenli bir anonim şirkettir. 1711 yılında George Caswall ile John Blunt tarafından kurulmuştur. Bu şirketin kuruluşunun arkasındaki ana unsur, İngiltere muhafazakâr parti hükümetinin ulusal borçlarını organize etmeye yardımcı olmak ve hükümeti desteklemektir (Akıncı vd., 2014:724). Özellikle İspanya Veraset Savaşı sırasında ekonomik sıkıntı içine giren İngiltere hükümeti Güney Denizi Şirketinden, Güney Amerika kolonilerinde sınırsız ticaret ve monopol hakkı vermesi karşılı̆̆ında ulusal borçları karşılamasını istemiş ve bunun için anlaşma imzalamıştır. Güney Denizi Şirketi yöneticileri, muhtelif senelik gelir poliçelerinden oluşan İngiltere Devlet Borcunu üstlenmeyi kabul etmişlerdir (Kurtoğlu, 2015:237). Bunun üzerine, hükümet borçlarını kapatabilmek için, 1719 yılında bir milyon poundu aşan değerde hisse senedi ihraç eden Şirket, hükümet borçlarını kapatmaya başlamış ve önemli sayılabilecek faiz kazançları da elde etmiştir (Akıncı vd., 2014:725). Hem hükümeti destekleyen bir konumda olması hem de hisse senedi ihracina gitmesi yatırımcılar tarafından olumlu karşılanan Şirketin hisse senetlerine büyük ilgi gösterilmiştir. Şirket, Güney Amerika'dan altın ve gümüş cevherleri, Avrupa'ya gelmek için bekliyor spekülasyonunu oluşturmuş dolayısıyla, gerçekçi olmayan bekleyişlerin ortaya atılması yatırımcılar ile spekülatörleri harekete geçirerek hisse senedi balonunun büyümesine yol açmıştır (Colombo, 2012a). 
İngiltere ve İspanya arasındaki savaş kendini göstermeye başlayınca ticaret yavaşlamaya başlamış, hatta durma noktasına gelmiştir. Ticaretin kötü gidişatını dikkate almayan yatırımcılar hisse senedi almaya devam etmiş ve kötü olan durum iyice vahim hale gelmiştir. Şirketin hisselerinin aşırı değerlendiği anlaşılınca, öncelikle yöneticiler ardından onları gören yatırımcılar hisselerini satmaya başlamışlardır. Sonuç olarak, fiyatlar hızlı bir biçimde düşüşe geçmiştir. Güney Denizi Şirketi'ne ait hisse balonunun patlaması ile oluşan kriz, birçok kişinin varlığını kaybetmesine neden olmuştur. Bu durum dünya tarihinin ilk finansal krizi olarak kabul edilmiştir (Speck, 1977:198).

\subsection{ABD Hisse Senedi ve Gayrimenkul Balonu ve 1929 Büyük Buhranı}

Büyük Buhran olarak da adlandırılan finansal kriz, Birinci Dünya Savaşı'ndan sonra 1929 yılında Amerika'da hisse senedi balonun patlaması sonucu ortaya çıkmış ve sadece Amerika'yı değil birçok ülkeyi etkisi altına almıştır. Büyük Buhran ilk küresel kriz olarak literatüre girmiştir. Sanayi alanında büyük gelişmeler içerisinde olan Amerika, Birinci Dünya Savaşı'ndan galip ayrılan ülkelerden bir tanesidir. Bu dönemde İngiltere, Fransa gibi ülkeler piyasalarını yeniden düzenlemek adına ABD'den yüklü miktarlarda kredi almışlardır.

1928 yılında Herbert Hoover'ın Başkanlığa seçilmesiyle, önceleri devlet tahvillerine yatırım yapan yatırımcılar, özel sektör şirketlerinin hisse senetlerine de yatırım yapmaya başlamışlardır. Yeterince likidite sahibi olmayan halk, kredi alarak diğer finansal sektörlere de yatırım yapmaya başlamış ve bu sayede kredi hacmi artmıştır. Ekonominin güçlü olduğuna inanan insanlar, aldıkları kredileri kolaylıkla geri ödeyebileceklerini düşünmüşlerdir (Gitlin ve Sylla, 2008: 8-15).

Piyasaların yükseliş trendinde olması ve refah bir ortamın olması, spekülasyon ortamı doğurmuş hem hisse senedi piyasalarını hem de reel piyasalardaki arzı arttırmıştır. Spekülatif bir hayal dünyasında yaşayan Amerika'da, inanması için ikna edilmesi gereken insanlardan ziyade, inanmak için bahane arayan insanların varlığı spekülasyonu artırmıştır (Yılmaz ve Kaygusuz, 2009:2). Ancak diğer Avrupa ülkeleri ekonomilerini düzeltme sürecine girmiş ve Amerika'ya olan bağımlılıklarını azaltmışlardır. Sonuç olarak, Amerika'da ticaret durgunlaşmaya başlamış ve üretilmiş olan mallar ellerinde kalmıştır. Bu süreçte kolay yoldan yüksek kazanç elde etmeyi amaçlayan Amerikalı yatırımcılar, sahip oldukları tasarruflarını bankalara yatırmak yerine hisse senedi piyasalarına yönlendirmeyi uygun görerek, bu piyasalardaki işlem hacimlerini artırmaya başlamışlardır (Akıncı vd., 2014:730). Böylece, yatırımcı kesim zenginleşirken yoksul kesim yoksul kalmaya devam etmiş ve iki kesim arasında uçurum oluşmuştur. İngiltere Maliye Bakanı'nın New York Borsası'nı inceledikten sonra yaptığı açıklamada Borsanın aslında spekülatif bir balon içinde olduğunu ve fiyatların aşırı değerlendiğini söylemesi üzerine hisse fiyatları hılı bir şekilde düşüşe geçmiş ve 24 Ekim 1929 tarihi "Kara Perşembe" olarak tarihe geçmiştir.

1920-1925 yılları arasında da bir başka spekülatif durum daha yaşanmıştır. Florida'da yaşayan insanlar, buradaki yaşam koşullarının elverişli olmasından dolayı burada gelecekte 
gayrimenkul değerlerinin artacağını düşünmüş ve gayrimenkullere yatırım yapmaya başlamışlardır. $\mathrm{Bu}$ yüzden spekülatif hareketler baş göstermeye başlamıştır. $\mathrm{Bu}$ çılgınlık evresi uzun sürmemiş 1926 yılında Miami Florida'da yaşanan kasırga felaketi ile birçok kişi hayatını kaybetmiş ve evler yıkılmıştır. Sonuç olarak, spekülatif balon patlamış ve gayrimenkul fiyatları dibe vurmuştur.

Yaşanan iki balonunda patlaması ile birlikte öncelikle Amerika daha sonra Avrupa ülkeleri etkilenmiştir. Yığın üretim şeklinde ortaya çıkan artan arz fazlaları, talep yetersizlikleri, finansal yapıları etkin olmayan kurumların varlı̆̆ı, ABD tarafından diğer ülkelere verilen kredilerin geri ödenmemesi, ihraç sektörünün çökmesi, Hoover yönetiminin krize müdahale etme yönünde adımlar atamaması ve gümrüklerin yükseltilmesi gibi sebepler, ifade edilen iki spekülatif balonun patlamasına ilaveten krizi tetikleyen diğer unsurlar olarak göze çarpmaktadır (Akıncı vd., 2014:733).

\section{4. İnternet (Dot-Com) Balonu}

Tarihteki Lale Çılgınlığı ve Güney Denizi balonlarında olduğu gibi egzotik ürünler ve uzak ülkelerin insanlarda bir çekim yaratması, büyük hayalleri harekete geçirmesi, bilinmezliğin yarattığı gizemin zenginlik hayallerini kıvılcımlandırması gibi, yeni teknolojiler de benzer etkilere sahiptir ve insanları bambaşka dünyalara taşıyabilmektedir. 1990'lı yıllarda teknolojik gelişmelerin artmasıyla internet ağları kurulmaya başlanmış, kişisel bilgisayarların sayısı artmıştır. $\mathrm{Bu}$ şekilde finansal piyasalar da, internet ortamına taşınmaya başlanmış ve piyasaların etkinliği artmıştır. Bu sayede IBM, AT\&T ve Microsoft gibi şirketler değer kazanmaya başlamış, bunu anlayan yatırımcılar spekülatif hareketler içerisine girmiş ve fiyatları daha yukarı taşımaya başlamıştır. Aynı zamanda 1990'lı yıllarda Amerika Merkez Bankası'nın düşük faiz politikası uygulaması ile yatırımcılar bu durumdan yararlanarak başlangıç sermayelerini düşük maliyetlerle finanse etmiş ve dolayısıyla da sermayedarlar internet ağları yardımıyla sanal şirketleşmeye başlamışlardır (Wollscheid, 2012:4 ).

Yapılan aşırı spekülasyonlar sonucu yatırımcıların teknoloji firmalarına yapmış oldukları aşırı yatırımlar, teknoloji borsası olarak da bilinen NASDAQ Menkul Kıymet Endeksi'nin değerinin yükselmesine neden olmuştur. 9 Mart 2000 tarihinde endeks 5.046,86 puan ile tarihi rekorunu kırmıştır.

Sanal ortamdaki bu olumlu konjonktür, 2000 yılı başında FED' in piyasa faiz oranlarını üst üste altı kez yükseltmesi nedeniyle kaybolmuş ve 1sınan ekonomi hız kaybetmeye başlamıştır (Akıncı vd., 2014:739). Yatırımcılar, FED' in politikası ile birlikte aslında spekülatif bir balonun içerisinde olduklarını anlamış ve oluşan panik ile birlikte almış oldukları teknoloji firmalarının hisse senetlerini satmaya başlamışlardır. Satım işlemleri arttıkça fiyatlar düşmeye başlamış ve içinde bulunulan balon patlamıştır. NASDAQ Endeksi $2.151,8$ puana kadar düşmüş, teknoloji firmalarının hisselerine yatırım yapan ya da yapmayan binlerce kişi sahip olduğu varlıkların tamamına yakın bir bölümünü kaybetmiş, işsizlik 
oranları artmış, reel kesim faaliyetleri yavaşlamış ve ekonomi durgunluk dönemine girmiştir (Colombo, 2007b).

\subsection{Küresel Finansal Kriz}

2000 y1lında Dotcom balonun patlamasıyla piyasalara olan güvenin sarsılmaya başlaması ve 11 Eylül 2001 tarihindeki saldırı ile ekonomik bir durgunluğa girilmesi krizin temellerini oluşturmuştur. Ekonomideki durgunluğu canlandırmak için Amerika Merkez Bankası faiz oranlarını düşürmeye başlamıştır. Bu amaçla 2001 'de \% 6,5 olan kısa vadeli faiz oranlarını 2003'e dek \% 1'e kadar indirmiştir (Kutlu, Demirci, 2011:122). Ayıca o dönemde enflasyon oranının 2,8 olması, yatımcıları gayrimenkul yatırımlarına talebe yönelten önemli nedenlerden olmuştur (http://www.usinflationcalculator.com). Talebin artmasiyla birlikte konut fiyatları da artış göstermeye başlamıştır. Bankalar, konut kredilerini teşvik etmek amacıyla kredi çeşitlendirmesine gitmişler ve kredi koşullarını esnekleştirerek özellikle geri ödeme olasılığı düşük olan tüketicilerin kredi kullanım oranının hızla artmasına neden olmuşlardır (Akıncı vd., 2014:740). Bankalar, kredi karşılığı alınan senetleri menkul kıymete dönüştürerek elden çıkarmış bu sayede riskli müşterilerin kâğıtları başka kurumlara hatta başka ülkelere gitmiştir.

2004 yılında FED' in faiz oranlarını arttırmaya başlamasıyla, gayrimenkul yatırımları durulurken, fiyatlarda düşüş trendi içerisine girmeye başlamıştır. Durumu fark eden gayrimenkul yatırımcıları, evlerini satıp kredilerini ödemek isteyince fiyatlarının düşüşünden dolayı borçlarını kapatamaz hale gelmişlerdir. Böylece, piyasalarda önce likidite darlı̆̆ olarak ortaya çıkan problemler, bir süre sonra finansal kurumların bilançolarındaki bozulma ile birlikte bu kuruluşları iflas tehlikesi ile karşı karşıya getirmiştir (Yılmaz, 2008:2). 2007 yılında gayrimenkul balonunun sönmesiyle, Ekim 2010'nun ortalarına kadar olan 3 yıllık dönemde 290'dan fazla banka ve tasarruf bankası, düzenleyici kuruluşlar tarafından kapanmaya zorlanmıştır (Bayar ve Kılıç, 2014:184).

$\mathrm{Bu}$ süreçte kendini gösteren ilk sıkıntı Amerika'daki en büyük mortgage şirketi olan Countrywide Financial'ın neredeyse batması ve Amerika Bankası'nın Ocak 2008'de şirketi almasıdır. Daha sonra 14 Mart'ta "Bulge Bracket" adı verilen çok uluslu 10 yatırım bankasından Bear Stearns, iflas durumuna gelmiş ve son anda JP Morgan Chase tarafindan satın alınmıştır. Bu olay, krizi gayrimenkul piyasasından sermaye piyasalarına taşıdı̆̆ için küresel krizin başlangıcını oluşturmuştur ( Grosse, 2010:7).

Eylül ayında son darbe gelmiş sırayla kredi ve sigorta kuruluşlarından Freddy Mac ve Fanny Mae, Eylül ayında boğucu portföylerinden kurtarılmıştır. Bir hafta sonrada Lehman Brothers Yatırım Bankası da iflas istemiştir. Aynı gün Merrill Lynch, Amerika Bankası tarafından satın alınmayı kabul etmiştir. Son olarak çok büyük Küresel Sigorta Şirketi olan AIG, ABD Hükümeti tarafından kurtarılmıştır ve bu durum krizin zirvesi olarak gösterilmiştir (Grosse, 2010:7). 
Sonuç olarak, ABD'de Hükümeti finansal sisteme güveni artırmak için finansal kurumlara doğrudan destek vermiştir. 2008 sonlarına doğru ABD Hükümeti iki büyük kurtarma paketi hazırlamıştır. 14 Ekim'de ABD Hazinesi tarafından çıkartılan Sorunlu Varlıkları Kurtarma Programı (TARP) ve Federal Rezerv tarafından 26 Kasım'da çıkartılan Kurtarma Paketi'dir. Bu tedbirlerden sonra, başka bir bankanın iflas etmemesi düşünülürse kurtarma paketleri işe yaramıştır. Ancak kriz, tüm dünyaya yayılmış ve üretim hacmi 2009 y1lı sonlarına kadar düşüş göstermiştir.

\section{KÜRESEL KRIZLERIIN DAVRANIŞSAL FINANS AÇISINDAN INCELENMESI}

Finansal krizleri; Rasyonel beklentiler, fayda fonksiyonunun maksimizasyonu ve bilgi şoklarına dayalı olarak açıklayan yerleşik iktisatın küresel finansal krizi öngörmede ve hatta krizin gerçekleşmiş bazı kısımlarını açıklamada yetersiz kalması, yerleşik iktisatın sorgulanmasına neden olmuştur (Bayar ve Kılıç, 2010:185). Bu yetersiz kalan alanlar, genellikle insan davranışlarının tahmininin güç hatta imkânsız olması ve öngörülememesidir. $\mathrm{Bu}$ alana davranışsal finans müdahale edebilmektedir.

Davranışsal finansın temel söylemi, yatırımcılar rasyonel değildir ve yatırım kararlarını verirken sadece kar maksimizasyonu amacını gütmemekte, duygularıyla da hareket etmektedirler. Örneğin bir hisse senedine yatırım yapan yatırımcı, rasyonel seçenek hisseyi satmak olsa bile, bunu yapmayıp elinde tutmak isteyebilir, ya da yine rasyonel bir seçenek olmamasına rağmen, başka yatırımcılar bir hisse senedine yoğun ilgi gösteriyor diye aynı hisse senedine yatırım yapılabilir. Bunun gibi durumları geleneksel teoriler ile açıklamak yetersiz kalmaktadir.

Davranışsal finans, psikolojiye atıf yaparak ve insan aklının yapısına dikkat çekerek bireysel ve kurumsal yatırımcılar tarafından yapılan hataları ortaya çıkarmaktadır (Szyszka, 2010: 121). Davranışsal finans, finansal piyasaların çalışmasına ilişkin iki konu üzerinde durmaktadır. Bunlardan ilki, yatırımcı psikolojisinin geleneksel finansal analiz teorileri tarafından varsayıldığı şekilde rasyonel davranmaya, engel olabileceğidir. Diğeri ise yatırımcıların yanlış fiyatlanmış varlıklara arbitraj yapma yeteneklerinin sınırlanmasıdır (Bayar ve Kılıç, 2014:185). Önemli iki husus sebebiyle finansal krizlerin davranışsal açıdan incelenmesi gerekli olabilir.

Davranışsal finans yanında, nöroekonomi de finansal balonların nedenlerini açıklamaya çalışmaktadır. Bunun için beyin fonksiyonları ve insan davranışları arasındaki ilişkiyi inceleyerek bir sonuca ulaşmayı amaçlamaktadır. Daha kesin bir cevap bulunamasa bile yapılan çalışmalar doğru yol üzerinde olunduğunu göstermektedir.

$\mathrm{Bu}$ çalışmalarda beynin iki fonksiyonu üzerinde durulmuştur. Bu fonksiyonlar limbik sistem içerisinde bulunan kayıptan kaçınma ve aşırı güven durumlarıdır. Aşırı güven durumunun bir finansal balonun oluşmasına, kayıptan kaçınma durumunun ise balonun 
sönmesine neden olduğu tartışılmaktadır. Bu durumda, hem nöroekonominin hem de davranışsal finansın üzerinde durduğu aşırı güven, kayıptan kaçınma ve korku başta olmak üzere sürü davranışı faktörleri üzerinden küresel krizlerin oluşmasını sağlayan finansal balonları açıklamak faydalı olabilir.

\subsection{Așırı Güven}

Washington Post'un yaptığı kamuoyu yoklamasına göre, Amerikalıların yüzde 94'ü dürüstlükte kendisini “ortalamanın üstünde” gördüğ̈nü söylemiş; yüzde 89'u sağduyulu olmak konusunda "ortalamanın üstünde", yüzde 86'sı zeka açısından "ortalamanın üstünde", yüzde 79'u da görünüş olarak “ortalamanın üstünde” olduğunu belirtmişlerdir. (Peterson, 2012:159). Görüldüğü üzere insanlar birçok özelliklerinde ortalamanın üzerinde olduklarını söylemişlerdir. Böyle bir durum ne kadar doğru bir tartışma konusu olabilir? Özgüven belli bir seviyeye kadar olumlu bir özelliktir. Özgüven olmadan kişiler birçok işe kalkışmak istemez ve çekingen olurlar. Ancak bu özelliğin aşırıya kaçması, olumludan olumsuza doğru bir çizgiye neden olmaktadır.

Finansal piyasalarda da aşırı güven performansı ciddi bir biçimde olumsuz etkilemektedir. Yüksek düzeyde özgüven ve denetim yanılsaması, alım-satım deneylerine katılan deneklerde gözlenen performans düşüklüğü ile ilişkilendirilmiş bulunmaktadır (Peterson, 2012:160). Yatırım yapılacak olan menkul değer ile ilgili aşırı bir özgüvenin olması o menkul değer hakkındaki haberlerin dikkate alınmamasına ve her hâlükârda yatırım yapılmasına neden olmaktadır. Așırı güven sonucu yatırım kararı verilmesinin en önemli sonucu finansal balonların oluşumudur. 2008 krizini ele alırsak, yatırımcılar gayrimenkul fiyatlarının artması ile birlikte bu sektöre yatırım yapmaya başlamış ve ileride de fiyatların artacağı, hiç düşmeyeceği ve faiz oranların hep düşük kalacağı düşünceleri ile aşırı bir öz güvene sahip olmuşlardır. Sonuç olarak, bu fiyatların yüksek seviyelerde seyretmesi yatırımcıları yıldırmamış alım işlemleri balon patlayıncaya kadar devam etmiştir. İyimserlik, sürekli daha yüksek getiri arayışı içerisinde yağma şeklinde kredi verilmesine ve etik davranışın çökmesine neden olmuştur (Bayar ve Kılıç, 2014:189).

Aşırı güvenin sonucunda kişiler riski önemsemeden yatırım yapmaktadırlar. 2008 krizinde gayrimenkul fiyatlarının yüksek seviyelere çıkması, yüksek riskin sinyalini vermiş olsa da kazanma duygusunun insan beyninde salgıladığı dopamin kimyasalı bu sinyallerin görülememesine neden olmuştur.

\subsection{Kayıptan Kaçınma, Korku}

Korku dürtüsü genel itibariyle sevilmeyen bir duygudur. Karanlıktan korkmak, yükseklikten korkmak genellikle kişilerin geçmişte yaşamış oldukları kötü olayların sonucu ortaya çıkmaktadır. Mesela karanlık bir ortamda kötü bir olay yaşayan ve korkan bir kişi daha sonra karanlık ortama girdiği her zaman olayı hatırlayarak korku dürtüsünü harekete geçirmektedir. $\mathrm{Bu}$ şekilde korku ile karanlık ilişkilendirilmiş olmaktadır. Emerson 
Üniversitesi'nde yapılan bir çalışmada, kişilerin korku düzeylerini ölçmek için şok tekniği kullanılmış ve bu süre zarfında beyin dalgaları incelenmiştir. Bazı kişilerin şoklardan aşırı korktuğu ve işlemin bir an önce bitmesi için daha yüksek voltaja maruz kalmaya razı oldukları görülmüştür. Şoku bekleme döneminde çok korkanların beyinlerindeki acı devrelerinin çok daha fazla çalıştığı bu sebeple bu kişilerin acıyı zihinlerinde yaşadıkları ve onlara gerçekmiş algısını yarattığ1 görülmüştür (Peterson, 2012:176).

Finansal piyasalar açısından korkuyu incelediğimizde Peter Lynch'in "Hisse senetlerinden para kazanmanın kilit unsuru, onlardan korkmamaktır" sözü önem arz etmektedir. Korku, çok ilkel bir dürtü olduğundan yatırım kararı verirken aklın ve mantığın devre dışı kalmasına ve yanlış seçimler yapılmasına neden olmaktadır. Yoğun korku kişilerde panik dalgaları oluşturmaktadır. Örneğin; Hisse senedine yatırım yapmış olan bir yatırımcı o hisse senedinin değerinin düştüğü haberini aldığında panikle karar vererek hemen hisse senedini elden çıkarmaya çalışır. Bir finansal balonun patlamasının en önemli etkilerinden bir tanesi bu korku ve panik durumudur. 2008 krizinde de gayrimenkul balonu, fiyatların düşüşe geçmesi ve bu düşüşten korkarak zarara girmek istemeyen yatırımcıların, ellerinde bulunan gayrimenkulleri satmaya başlamasıyla patlamıştır. Panik güdülü satışlar, fiyat düşüşlerindeki artışları yükseltmiş böylece küresel finansal krizin başlangıç evresinde korku, paniğe dönüşerek oluşturduğu düşüş sarmalı, varlıkların değer kaybını arttırmıştır (Bayar ve Kılıç, 2014:188). Panik bir kere yaşandıktan sonra belli bir süre aynı işlem tekrarlanmaz ve unutulmaya çalışılır. Aynı durum küresel kriz içinde geçerli olmuştur. Spekülatif balon sönmeye başladıktan sonra, özellikle mortgage işlemine dayalı türev ürünlerinden hızla kaçış, söz konusu finansal ürünleri değersiz hale getirmiştir (Bayar ve Kılıç, 2014:189).

\section{SONUÇ}

İnsanı insan yapan organ beyindir. Kalbimize atmasını söyleyen ciğerlerimize hava dolmasını sağlayan kısacası tüm vücudumuzun çalışmasını sağlayan yegâne organdır. Beynimizde oluşan küçücük bir problem, bazen fizyolojik olarak değişime bazen psikolojik değişime bazen ölüme bile sebep olmaktadır. Beynimiz ile ilgili açıklanamayan çok fazla bölge olması bilinmezliğe, bilinmezlik ise korkuya sebebiyet vermektedir. Yapılan araştırmalar ile bu bilinmezlik en aza indirilmeye çalışılmaktadır.

Son y1llarda ekonomi ve finans dünyasında açıklanamayan birçok olay, genel geçer kuralları yıkmaya başlamış ve yeni arayışlara sebebiyet vermiştir. Geleneksel teoriler insanların rasyonel olduğunu ve piyasalarda rasyonel davranışlar sergilediğini varsaymaktadır. Ancak bu durumun yanlışlığını, günümüzde literatürde çok çalışılmış olan davranışsal finansın bir konusu olan anomalilerde görmekteyiz. Anomaliyi mantığın açıklayamadığı matematiksel olarak bir yere oturmayan, olağanın dışında görülen durumlar olarak tanımlayabiliriz.

Davranışsal finans, Daniel Kahneman ve Amos Tversky tarafından ortaya atıldıktan sonra hızlı bir ivmeyle ekonomi finans dünyasına kendisini kabul ettirmiş ve ayrı bir dal 
olarak yerini almıştır. Aynı şekilde davranışsal finansın da yetmediği konuları anlamak adına daha derine inilmesi gerektiğine karar verilmiş ve beyin ile finans arasındaki ilişki incelenmeye başlanmıştır. Nörofinans ya da daha yaygın ismiyle nöroekonomi hem çok yeni bir alan olması hem de birçok dalı bir araya getirmesi nedeniyle popülerlik kazanmıştır.

Geleneksel ekonomi, finans teorileri ve davranışsal finansın açıklayamadığı finansal balonları açıklayabilme ihtimali nöroekonominin popülerliğini arttırmaktadır. Küresel krizlerin oluşumunda büyük bir payı olan finansal balonun anlaşılabilmesi ve belli bir sisteme oturtulabilmesi, gelecek krizlerin önlenebilmesi açısından çok büyük bir adım olarak sayılabilir. Nöroekonomi araştırmalarına göre, finansal bir balonun içindeyken yatırımcılar, balonu bir rakip olarak görmekte ve bu durum, finansal karar verilirken kullanılan beyin sürecini değiştirmektedir (De Martino vd.,2013). Başka bir deyişle yatırımcılar, diğer yatırımcıların hareketlerini tahmin etmeye çalışmaktadır. Bu durumda yatırımcılar, gerçek fiyatlardan ziyade, piyasanın gelecekteki fiyatlarının ne olacağına odaklanmaktadırlar. Diğer yatırımcıların hareketlerini tahmin etme durumunu oyun teorisine de benzetmek mümkündür (Braeutigam, 2005:355). Günlük hayatta bu durum kişilerin birbirleriyle iyi geçinmesine yardımcı olabilir. Ancak çok karışık bir sistem olan finansal piyasalarda uygulanmaya çalışıldığında, balonlar oluşmakta, giderek büyümekte ve belli bir noktadan sonra patlamaktadir.

De Martino'ya göre; Piyasaları yaratan insanlardır sayılar değil. Aynı zamanda insan beyni, herhangi bir finansal piyasadan önce var olmuştur. Bu nedenle piyasaları anlamak için önce beyni anlamamız gerekmektedir. Yapılan çalışmalar, daha çok yeni olmasına rağmen gelinen nokta ilgi çekici olup aynı zamanda bu çalışmaların, ileride insan davranışlarının iç yüzünü anlamakta yardımcı olacağı tahmin edilmektedir.

$\mathrm{Bu}$ çalışma, davranışsal finans ve nörokonominin krizleri açıklamada kullanılabileceği vurgusuna dikkat çekmektedir. Finans literatüründe çokça işlenen krizler, hisse senedi yatırımcı davranışları, yatırım kararlarının alınması gibi pekçok konu, davranışsal finans ve nöroekonomi bilimi ışığı altında incelenmeye başlamıştır. Bu çalışmalara devam edilmesi, geleneksel teorilerle açıklanamayan krizler hakkında daha çok bilgiye sahip olmamızı sağayabilir

\section{KAYNAKLAR}

Akıncı, Merter.- Yüce Akıncı, Gönül - Yılmaz, Ömer. (2014), "Lale Çılgınlığından Mortgage Krizine Spekülatif Balonlar.", Tarih Okulu Dergisi, Cilt 7, Sayı 19, ss. 719-749.

Bayar, Yılmaz. - Kılıç, Cüneyt. (2013), "Küresel Finansal Krizin Davranışsal Finans Perspektifinden İncelenmesi", İktisat Fakültesi Mecmuas1, Cilt 62, Say1 2, ss. $177-$ 195.

Colombo, Jesse. (2012a), The South Sea Bubble, www.thebubblebubble.com. 
Colombo, Jesse. (2012b), The Dot-Com Bubble. Erişim Tarihi: 02.01.2013, http://www.stock-market-crash.net/dot-com-bubble/. (Aktaran Akıncı, Merter, Gönül Yüce Akıncı, ve Ömer Yılmaz. (2014) "Lale Çılgınlığından Mortgage Krizine Spekülatif Balonlar.", Tarih Okulu Dergisi, Cilt 7, Sayı 19, ss. 740).

De Freitas, Will. - De Martino, Benedetto. - Taffler Richard. (2013), "Neuroscience May Help Us Understand Financial Bubbles", http://theconversation.com.

Duman, Erhan. (2011), "Krizlerin Anatomisi: 1929 Ekonomik Buhranı ve 2008 Küresel Krizinin Karşılaştırılması." Yüksek Lisans Tezi, Karaman: Karamanoğlu Mehmet Bey Ünivesitesi Sosyal Bilimler Enstitüsü.

Eğilmez, Mahfi. (2008), "Balonlar Lale Çılgınlığıyla Başladı", www.radikal.com.tr.

Flood, Robert P.- Garber, Peter M. (1980), "Market Fundamentals versus Price-Level Bubbles: The First Tests", Journal of Political Economy, Cilt 88, Say1 4, ss. 745-770.

Gitlin, Martin. - Richard, Sylla. (2008), The 1929 Stock Market Crash. USA: ABDO Publishing. (Aktaran Akıncı, Merter, Gönül Yüce Akınc1, ve Ömer Yılmaz. (2014) "Lale Çılgınlığından Mortgage Krizine Spekülatif Balonlar.", Tarih Okulu Dergisi, Cilt 7, Sayı 19, ss. 730).

Grosse, Robert.( 2010), "The Global Financial Crisis - A Behavioral View", Social Science Research Network.. http://papers.ssrn.com/sol3/papers.cfm?abstract_id=1537744.

Kurtoğlu, Ramazan. (2015), Küresel Para Savaşları ve Davranışsal Ekonomisi Nörofinans, Orion Kitabevi, Ankara.

Kutlu, Hüseyin Ali. - Demirci N. Savaş. (2011), "Küresel Finansal Krizi (2007-?) Ortaya Çıkaran Nedenler, Krizin Etkileri, Krizden Kısmi Çıkış ve Mevcut Durum", Muhasebe ve Finansman Dergisi, ss. 121-136.

Peterson, Richard L. (2012), Aklın Para Üzerindeki Gücü Karar Anı, Scala Yayıncılık, İstanbul

Smith, Alec. - Lohrenz, Terry. - King, Justin. - Montague, P. Read. - Camerer, F. Colin. (2014), "Irrational Exuberance and Neural Crash Warning Signals During Endogenous Experimental Market Bubbles.", Proceedings of the National Academy of Sciences, Cilt 111, Say1 29, ss. 10503-10508.

Soydal, Haldun. - Mizrak, Zekeriya - Yorgancilar, Fatma Nur. (2010) "Nöroekonomi Kavramının İktisat Bilimi İçindeki Yeri, Önemi, Bilimselliği", Sosyal ve Ekonomik Araştırmalar Dergisi, Sayı 19, ss. 215-240.

Speck, William Arthur. (1977). Stability and Strife: England, 1714-1760. USA: Harvard University Press. (Aktaran Akınc1, Merter, Gönül Yüce Akınc1, ve Ömer Yılmaz. (2014) "Lale Çılgınlığından Mortgage Krizine Spekülatif Balonlar.", Tarih Okulu Dergisi, Cilt 7, Say1 19, ss. 726). 
Szyszka, Adam. (2010), "Behavioral Anatomy of the Financial Crisis", Journal of CENTRUM Cathedra, Cilt 3, Sayı 2, ss.121-135.

Tufan, Ekrem. (2008), Davranışsal Finans: Finansal Kararları Yönlendiren Sosyal Psikolojik Anomalilerin Davranışsal Finans Bağlamında İncelenmesi ve İMKB Açısından Değerlendirmesi, İmaj Yayınevi, Ankara.

Wollscheid, Christian. (2012), Rise and Burst of the Dotcom Bubble: Causes, Characteristics, Examples. Germany: GRIN Verlag. (Aktaran Akıncı, Merter, Gönül Yüce Akıncı, ve Ömer Yılmaz. (2014) "Lale Çılgınlığından Mortgage Krizine Spekülatif Balonlar.", Tarih Okulu Dergisi, Cilt 7, Sayı 19, ss. 739).

Yılmaz, Durmuş. (2008), "Küresel Mali Kriz ve Türkiye Ekonomisine Etkileri: Nasıl Başladı, Hangi Aşamadayız?", Türkiye Cumhuriyet Merkez Bankası, ss. 1-11.

Yılmaz, D. ve Gayğusuz, F.(2009), 2008 Krizinin Yeni Ekonomik Yapı Üzerine Etkileri: http://idc.sdu.edu.tr/tammetinler/kalkinma/kalkinma39.pdf, Erişim Tarihi: 22.04.2010 (Aktaran Duman, Erhan. (2011), "Krizlerin Anatomisi: 1929 Ekonomik Buhranı ve 2008 Küresel Krizinin Karşılaştırılması." Yüksek Lisans Tezi, Karaman: Karamanoğlu Mehmet Bey Ünivesitesi Sosyal Bilimler Enstitüsü, ss. 57).

\section{İnternet Kaynakları}

http://www.latimes.com/science/sciencenow/la-sci-sn-irrational-markets-20140710-story.html (Erişim Tarihi: 28.11.2015).

http://www.neurogistics.com/thescience/whatareneurotransmi09ce.asp Erişim Tarihi:

26.11http://www.latimes.com/science/sciencenow/la-sci-sn-irrational-markets20140710-story.html (Erişim Tarihi: 28.11.2015).

http://www.usinflationcalculator.com/inflation/current-inflation-rates/ (Erişim Tarihi: 23.12.2015).

www.thebubblebubble.com (Erişim Tarihi: 24.12.2015). 
